MODERN REALISM IN ENGLISH-CANADIAN FICTION 
This page intentionally left blank 


\section{COLIN HILL}

\section{Modern Realism in \\ English-Canadian Fiction}

UNIVERSITY OF TORONTO PRESS

Toronto Buffalo London 
(C) University of Toronto Press 2012

Toronto Buffalo London

www.utppublishing.com

Printed in Canada

ISBN 978-1-4426-4056-6

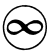

Printed on acid-free, $100 \%$ post-consumer recycled paper with vegetable-based inks.

\section{Library and Archives Canada Cataloguing in Publication}

Hill, Colin, 1970-

Modern realism in English-Canadian fiction / Colin Hill.

Includes bibliographical references and index.

ISBN 978-1-4426-4056-6

1. Canadian fiction (English) - 20th century - History and criticism.

2. Realism in literature. 3. Modernism (Literature)-Canada. I. Title.

$$
\text { PS8191.R37H54 } 2012 \text { C813'.520912 C2011-907911-9 }
$$

A section of chapter 2 was previously published in Canadian Literature 195. Sections of chapter 4 have been published in different forms in Journal of Canadian

Studies 44.3 (2010) and in The Canadian Modernists Meet: Essays on Modernism, Antimodernism and Modernity, ed. Dean Irvine (2005).

University of Toronto Press acknowledges the financial assistance to its publishing program of the Canada Council for the Arts and the Ontario Arts Council.

\section{Canada Council Conseil des Arts for the Arts du Canada

This book has been published with the help of a grant from the Canadian Federation for the Humanities and Social Sciences, through the Aid to Scholarly Publications Program, using funds provided by the Social Sciences and Humanities Research Council of Canada.

University of Toronto Press acknowledges the financial support of the Government of Canada through the Canada Book Fund for its publishing activities. 
For Olivier 
This page intentionally left blank 